\title{
Poor obstetric outcomes in Indian women with Takayasu arteritis
}

Latika Gupta, Durga Prasanna Misra, Sakir Ahmed, Avinash Jain, Abhishek Zanwar, Able Lawrence, Vikas Agarwal, Amita Aggarwal and Ramnath Misra ${ }^{*}$ (i)

\begin{abstract}
Introduction: Takayasu's arteritis (TA) affects young women in the childbearing age group. We studied obstetric outcomes in these patients before and after disease onset.

Methods: Women aged more than 18 years with Takayasu's arteritis (ACR 1990 criteria) were included. Demographic data, clinical features, disease activity using Indian Takayasu Arteritis clinical score (ITAS), Disease Extent Index for TA (DEI.TaK) and damage assessment using TA Damage score (TA), history of conception and maternal and fetal outcomes were recorded from hospital records and telephonic interview. Results are in median and IQR.

Results: Of the 64 women interviewed, aged 29 (24-38) years and disease duration 5 (4-10) years, 74 and 38 pregnancies had occurred before and after disease diagnosis in 29 and 20 women respectively. In eight, the diagnosis was made during pregnancy. Age at disease onset was 22 (18-30) years. Type 5 disease was the most common ( $n=32,59.3 \%)$, and an equal number of patients had Ishikawa's class I and II disease $(n=26,40.6 \%)$. Median ITAS $(n=44)$ was 13 (7-16), DEl.Tak 12.5 (9-16.75) and TADS 8 (6.5-10). Twenty-five patients wanted to get pregnant, of which 8 (32\%) did not do so because of their disease. Fifteen were unmarried of whom 6 did not marry due to disease. Obstetric outcomes were poorer in pregnancies that occurred after the onset of disease as compared with those before it $(R R=1.5, p=0.01)$. Pregnancies after the onset of TA carried a very high risk of maternal [RR3.9 (1.8-8.5), $P<0.001]$ as well as fetal complications $[R R=2.0(1.2-3.4), p=0.001]$. Hypertension was the most common maternal complication and occurred most often in the last trimester. The baby weight at birth was lower in pregnancies after disease (2.3 vs. 3.0, $p=0.01)$. Wong's score greater than or equal to 4 predicted lower birth weight $(p=0.04)$. ITAS, ITAS-A, DEl. Tak and TADS could not predict obstetric outcomes, and ITAS score exhibited moderate correlation with DEl. Tak $(r=0.78)$ and TADS $(r=0.58)$.
\end{abstract}

Conclusion: Women with TA suffer from extremely high risk of poor maternal and foetal outcomes. Wong's scoring can be useful to predict birth weight.

Keywords: Takayasu, Vasculitis, Pregnancy, Obstetric, Outcomes, Disease activity

\section{Key messages}

- Pregnancy in women with Takayasu's arteritis is associated with maternal and fetal morbidity

- Hypertension is the single most important complication

- Wong's score can predict outcomes in the neonate in TA

\footnotetext{
* Correspondence: rnmisra2000@gmail.com

Department of Clinical Immunology and Rheumatology, Sanjay Gandhi

Postgraduate Institute of Medical Sciences, Lucknow 226014, India
}

\section{Introduction}

Takayasu arteritis (TA) is a large vessel vasculitis predominantly found in Asian populations [1]. Recently various treatment options have come up, including multiple biologicals [2]. This, along with improved medical care, is bringing down mortality in this dreaded disease [3]. However, there is a lack of specific quality of life measures for Takayasu [4]. Thus, in the absence of specific measures, pregnancy outcomes could serve as an indirect measure of morbidity in this disease seen more often in females.

(c) The Author(s). 2020 Open Access This article is distributed under the terms of the Creative Commons Attribution 4.0 International License (http://creativecommons.org/licenses/by/4.0/), which permits unrestricted use, distribution, and 
Majorities of rheumatic diseases are more common in females, especially in the reproductive age group. Presence of rheumatic diseases often leads to lower fertility. This can be due to disease-related factors including drugs (impaired gonadal functioning, pregnancy loss, therapy-related avoidance of pregnancy) or due to psychosocial reasons (personal choice, depression leading to loss of libido, anxiety, altered self-image, etc) [5].

Takayasu is no different. It predominantly affects young women with a female to male ratio of 9:1. Most of the other vasculitis affect women beyond their reproductive years [6]. Still, overall fertility is reduced in vasculitis: pregnancy losses have been reported in around $10 \%$ of cases in granulomatosis with polyangiitis, up to $20 \%$ in eosinophilic granulomatosis with polyangiitis, $20-30 \%$ in Behçet's disease and up to $25-30 \%$ of TA in the developed world [7]. In a study in France, women with TA had a 13-fold higher risk of obstetric complications after diagnosis of pregnancy as compared to before [8]. Some studies have even shown no effect of TA on obstetric outcomes [9].

The scenario in India may be different [10]. In TA, it is well established that the pattern of vascular involvement differs by region with a plausible role of dynamic interactions of the genes with the environment. Vascular dynamics in pregnancy are likely to be differentially affected depending on vessel involvement. Type $\mathrm{V}$ with predominant abdominal aorta is most common in Indian patients [11].

The obstetric outcomes in Indian women are lesser known. The first series reported from India was from an institute in Northern India of 12 patients with 24 pregnancies (1979-1999, [12]. The authors followed this up with a second series (1999-2008) with 37 pregnancies in 15 women [13]. Another series is available from Eastern India which reported 16 patients with 29 pregnancies [14]. However, these were mostly Ishikawa Group IIa.

Also, the utility of outcome measures for disease activity such as ITAS [15] and DEI.TaK and for damage (TADS) [16] for prediction of pregnancy outcomes is unclear. A seminal paper by Wong et al. has suggested a score which can be used to predict fetal morbidity and gives room for pre-emptive escalated obstetric care [17].

Hence, we sought to explore the obstetric outcomes in patients with TA by comparing them in women who conceived before and after disease onset. In addition, the predictive value of ITAS, DEI. Tak, TADS and Wong's score were tested for association with obstetric outcomes.

\section{Methods}

This was a retrospective study in a cohort of patients from a single tertiary care centre in Northern India. Ethics permissions were taken from the institute ethics committee. All women with Takayasu's arteritis by 1990 ACR criteria, above 18 years of age, were recruited. Data on demographic parameters, clinical profile and comorbidities were collected from hospital records and supplemented by a personal or telephonic interview in July 2017. Patients with age of disease onset more than 40 years were excluded. Where available, angiography records, ITAS, ITAS-A (ITAS with acute phase reactants), DEI.TaK and TADS scores were retrieved from the records. Data from all sources were used to calculate the Wong's prognostic score for newborns (Table 1).

Outcomes included fertility and pregnancy outcomes. Fertility outcomes were early menopause (defined as presence of sustained amenorrhea for more than 1 year after attaining menarche, before 40 years of age), deferring pregnancy due to disease process, inability to conceive, and abstinence due to drugs or disease activity. Data on contraception use was also collected.

Pregnancy outcomes were divided into maternal and fetal outcomes. Maternal outcomes were flare of disease, hypertensive diseases of pregnancy, diabetes, abortions (spontaneous or induced), stillbirths and live-births. Fetal outcomes were prematurity, low birth weight, congenital anomalies, or neonatal deaths.

Data analysis was carried out using GraphPad Prism` 7 and SPSS $\odot 20$ software. Since data was mostly nonparametric, it was represented as median (Intra-quartile range: IQR). Fisher's Exact test for comparing proportions and Man-Whitney $U$ test for comparing means were used. To estimate the effect of disease on various outcomes, the pregnancies before disease onset were taken as controls. The relative risk of different outcomes was calculated. Two mixed generalised models with age, duration of disease, diagnostic category, education status, place of residence, and age at conception as covariates was used to determine the factors influencing maternal and foetal outcomes respectively.

Table 1 Wong's prognostic scoring for neonate born to mother with Takayasu's arteritis

\begin{tabular}{lllll}
\hline Score & $\begin{array}{l}\text { Involvement of } \\
\text { abdominal aorta }\end{array}$ & $\begin{array}{l}\text { Trimester when } \\
\text { treatment started }\end{array}$ & $\begin{array}{l}\text { Highest Mean arterial } \\
\text { pressure in 3rd Trimester }\end{array}$ & $\begin{array}{l}\text { Super-imposed } \\
\text { pre-eclampsia }\end{array}$ \\
\hline 0 & No & 1 st & $<100$ & None \\
1 & Yes & 2nd & $101-130$ & 3rd Trimester \\
2 & Yes + Renal & 3rd & $>130$ & 1st-2nd Trimester \\
& & & & \\
\hline
\end{tabular}




\section{Results}

\section{Clinical profile of patients with TA}

Sixty-four women with median age and disease duration 29 (IQR 24-38) years and 5 (4-10) years respectively were interviewed. Median age at menarche was 13 (12.5-15) years. Menstrual patterns were unchanged after the onset of disease. Five (7.8\%) were postmenopausal. Median age at menopause was 44 (40-47.5) years. Table 2 highlights the demographic profile of the patients.

\section{Social impact and conception}

Fifteen of the 64 interviewed (23.4\%) were unmarried, and six $(40 \%)$ of them attributed it to the disease. Of those who were married, 25 wished to conceive, but 8 (32\%) decided against due to the disease. One had infertility with no other cause found and the infertility was attributed to Takayasu by the treating physician.

Of the forty-nine married women, 32 had discussed contraceptive issues with their physicians. The others had declined due to personal preferences or lack of need. Barrier method was the most common $(n=21)$ mode of contraception.

Table 2 Demographic profile of interviewed patients

\begin{tabular}{ll}
\hline Characteristics & Women with TA $(n=64)$ \\
\hline Age $^{a}$ & $29(24-38)$ \\
Disease duration $^{a}$ & $5(4-10)$ \\
Age of disease onset $^{\mathrm{a}}$ & $22(18-30)$ \\
Clinical Profile & $\mathbf{N}$ \\
Type of TA (Angiographic) & \\
I & $15(23.4)$ \\
IIb & $4(6.2)$ \\
III & $2(3.1)$ \\
IV & $1(1.6)$ \\
V & $32(50)$ \\
Unknown & $10(15.6)$ \\
Ishikawa type & \\
1 & $11(17.1)$ \\
2 & $26(40.6)$ \\
3 & $12(18.8)$ \\
Unknown & $15(23.4)$ \\
Outcome Measures $(n=44)$ & \\
ITAS & $13(7-16)$ \\
ITAS A & $15(7.25-18)$ \\
DEl.Tak & $12.5(9-16.75)$ \\
TADS & $8.5-10)$ \\
\hline
\end{tabular}

${ }_{\text {in years [Median (IQR)]. For abbreviations (see text) }}$

\section{Obstetric outcomes in TA}

Seventy-four conception events occurred before the diagnosis of TA in 30 women while 38 were after the diagnosis in 26 women (Table 3 ).

Out of 38, there were 10 spontaneous abortions, 6 medical termination of pregnancy (MTP) and 19 live births (Fig. 1). Of the live births, 10 had foetal morbidity (Table 4). Six had low birth weight and one each had neonatal sepsis and meconium-stained liquor. Four of the six MTPs were advised due to inadvertent iatrogenic exposures (2 Methotrexate, 1 Azathioprine, and Computed tomogram (CT) scan done with foetus in utero) at another hospital and one due to uncontrolled hypertension while for the sixth one reason was unclear. Of maternal complications, hypertension was the most common, seen in 15 pregnancies of the 38, most often in the last trimester (Table 4). Of the 11 children whose birth weight was available, 6 had weighed normal at birth while 4 were of low birth weight and one was macrosomic.

Table 3 Women with TA who conceived before or after the diagnosis

\begin{tabular}{|c|c|c|}
\hline Characteristic & $\begin{array}{l}\text { Patients with } \\
\text { conception } \\
\text { before the } \\
\text { diagnosis of } \\
\text { TA }(n=30)\end{array}$ & $\begin{array}{l}\text { Patients with } \\
\text { conception } \\
\text { concurrent or } \\
\text { after the diagnosis } \\
\text { of TA }(n=26)\end{array}$ \\
\hline$\overline{\mathrm{Age}^{a}}$ & $40(32-44.5)$ & $30(27-33.5)$ \\
\hline Disease duration $^{\mathrm{a}}$ & $7(4-14)$ & $6.5(3-11.8)$ \\
\hline Age of disease onset ${ }^{\mathrm{a}}$ & $30(25-35)$ & $23.5(20.5-27.1)$ \\
\hline Clinical Profile & $\mathrm{N}$ & \\
\hline \multicolumn{3}{|c|}{ Type of TA (Angiographic) } \\
\hline । & $9(30)$ & $4(15.4)$ \\
\hline$\| \mathrm{b}$ & $4(13.3)$ & $2(7.7)$ \\
\hline III & 0 & 0 \\
\hline IV & 0 & 0 \\
\hline V & $15(50)$ & $16(61.5)$ \\
\hline Unknown & $2(6.7)$ & $4(16.7)$ \\
\hline \multicolumn{3}{|l|}{ Ishikawa type } \\
\hline 1 & $5(16.7)$ & $4(16.7)$ \\
\hline 2 & $14(46.7)$ & $10(38.5)$ \\
\hline 3 & $6(20)$ & $4(16.7)$ \\
\hline Unknown & $6(20)$ & $8(30.8)$ \\
\hline \multicolumn{3}{|c|}{ Outcome Measures $(n=44)$} \\
\hline ITAS & $14(7-17)$ & $14.5(9.3-17.8)$ \\
\hline ITAS A & $15.5(7.3-20)$ & $11(2-20.5)$ \\
\hline DEI.Tak & $13(9-17)$ & $17(12.5-19)$ \\
\hline TADS & $8(6.5-11)$ & $8(7-10)$ \\
\hline
\end{tabular}

${ }_{\text {in years [Median (IQR)]. For abbreviations (see text) }}$ 


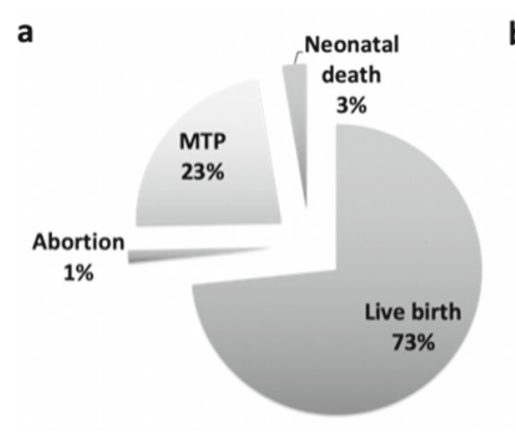

n, 74

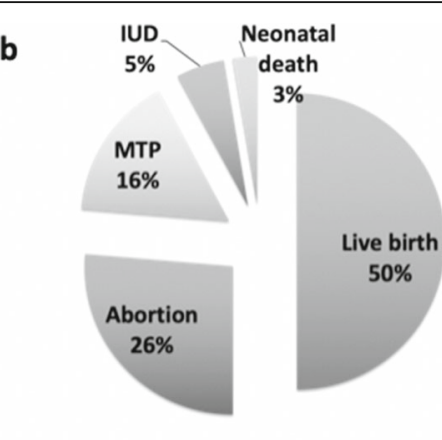

n, 38

IUD, Intra-uterine death; MTP, Medical Termination of pregnancy; $n$, number of patients

Fig. 1 Obstetric outcomes of conception before and after diagnosis of TA. $\mathbf{a}$ and $\mathbf{b}$ Obstetric outcome before and after the diagnosis of TA respectively. IUD, Intra-uterine death; MTP, Medical Termination of pregnancy; n, number of patients

\section{Peripartum diagnosis of disease}

Eight women had a diagnosis of TA during pregnancy, of which only 2 had prior (undiagnosed) symptoms.

\section{Comparisons between obstetric outcomes before and after onset of TA}

Obstetric complications were more common in pregnancies after the onset of TA as compared with those before $(\mathrm{RR}=1.5, p=0.01$. Figure 1$)$. Pregnancies after TA onset had higher maternal complications $(R R=3.9(1.8-8.5)$,

Table 4 Maternal and fetal complications in conceptions before and after diagnosis of Takayasu arteritis

\begin{tabular}{lll}
\hline Obstetric outcomes & $\begin{array}{l}\text { Before TA } \\
(n=74, \%)\end{array}$ & $\begin{array}{l}\text { After TA } \\
(n=38, \%)\end{array}$ \\
\hline Maternal complications & $1(1.3)$ & $15(39.4)$ \\
Hypertension & 0 & $2(5.2)$ \\
Post-dated & 0 & $2(5.2)$ \\
Gestational Diabetes & $1(1.3)$ & $1(2.6)$ \\
Premature rupture & & \\
of membranes & $1(1.3)$ & $1(2.6)$ \\
Prolonged labour & 0 & $1(2.6)$ \\
Jaundice & 0 & $1(2.6)$ \\
Polyhydramnios & $2(1.6)$ & 0 \\
Post-Partum Haemorrhage & $1(1.3)$ & 0 \\
Anti-Partum Haemorrhage & & $6(15.8)$ \\
Fetal complications & $2(1.6)$ & $2(5.2)$ \\
Low Birth Weight & $4(5.4)$ & 0 \\
Preterm & $1(1.3)$ & $1(2.6)$ \\
Congenital malformation & $1(1.3)$ & $1(2.6)$ \\
Meconium stained Liquor & 0 & 0 \\
Neonatal sepsis & $1(1.3)$ & \\
Neonatal jaundice & &
\end{tabular}

$P<0.001)$ as well as fetal complications $(\mathrm{RR}=2.0(1.2-$ $3.4), p=0.001)$. Conception after the diagnosis of TA was more likely to result in abortions as compared to conception before TA diagnosis (RR 3.6, $p<0.0001$ ).

Baby weight at birth was lower in pregnancies after disease diagnosis $(2.3 \mathrm{~kg}$ vs $3.0 \mathrm{~kg}, p=0.01)$. Wong's score $\geq 4$ was associated with lower birth weight ( $p=$ 0.04). ITAS, ITAS A and TADS $(n=15)$ at baseline could not predict outcomes (Area under Curve - 0.5 \& 0.7) and did not correlate with Wong's score.

In the multivariate analyses, age at disease onset, disease duration, type of TA, ITAS, or TADS were not associated with obstetric outcomes, including maternal or fetal complications individually or combined.

\section{Discussion}

Women with TA had poor obstetric outcomes, with increased risk of maternal as well as fetal complications. Hypertension was the most common maternal complication. Peripartum diagnosis was established in $12.5 \%$ of all cases. Angiographic type, disease activity measures like ITAS, DEI.Tak and damage score TADS could not predict pregnancy outcome. However, Wong's score envisaged neonatal outcomes.

Similar to our data, poor obstetric outcomes are seen in most series, though most lack a valid control group for comparison (Table 5) [8, 9, 12-14, 18-22]. Although hypertension is the most reported complication through most series, the percentages vary remarkably. While all prospective series describe hypertension in almost three fourths or more, all retrospective data sets (e.g. from Osaka and another multicentre from France), including the current one, describe HTN in $15-40 \%$ of women.

While most other studies describe live birth rates of around $80 \%(65-100 \%)$, our study had a lower percentage of live births $(50 \%)[8,9,12,13]$. Implications from 
Table 5 Comparison of obstetric outcomes in Takayasu arteritis across the world

\begin{tabular}{|c|c|c|c|c|c|c|c|c|c|}
\hline $\begin{array}{l}\text { Centre (year } \\
\text { of } \\
\text { publication) }\end{array}$ & $\begin{array}{l}\text { No of } \\
\text { Pregnancies }\end{array}$ & Hypertension & $\begin{array}{l}\text { Fetal } \\
\text { complications }\end{array}$ & $\begin{array}{l}\text { Live } \\
\text { birth- } \\
n(\%)\end{array}$ & $\begin{array}{l}\text { Maternal } \\
\text { mortality }\end{array}$ & $\begin{array}{l}\text { Wong's } \\
\text { scoring }\end{array}$ & $\begin{array}{l}\text { Disease } \\
\text { active }\end{array}$ & Controls & Conclusion \\
\hline $\begin{array}{l}\text { Wong et al., } \\
\text { Hong Kong } \\
\text { (1983) [17] }\end{array}$ & 19 & $16(84.2 \%)$ & $9(60 \%)$ & $\begin{array}{l}15 \\
(78.9 \%)\end{array}$ & $\begin{array}{l}1(5.2 \%)- \\
\mathrm{Ml}\end{array}$ & Yes & 0 & $\begin{array}{l}\text { Yes-TA } \\
\text { before } \\
\text { diagnosis }\end{array}$ & $\begin{array}{l}\text { IUGR can be predicted by scoring } \\
\text { system }\end{array}$ \\
\hline $\begin{array}{l}\text { PGI } \\
\text { Chandigarh, } \\
\text { India(2000) } \\
{[12]}\end{array}$ & 24 & $22(91.7 \%)$ & $9(52.9 \%)$ & $\begin{array}{l}17 \\
(70.8 \%)\end{array}$ & 0 & No & NA & No & $\begin{array}{l}\text { Abdominal vessel disease \& delay } \\
\text { in care predict poor outcomes }\end{array}$ \\
\hline $\begin{array}{l}\text { University de } \\
\text { Estado, Brazil } \\
\text { (2012) [18] }\end{array}$ & 11 & $7(63.6 \%)$ & $7(63.6 \%)$ & $\begin{array}{l}11 \\
(100 \%)\end{array}$ & 0 & No & 0 & No & $\begin{array}{l}\text { Close monitoring with combined } \\
\text { care is usedful; No disease activity } \\
\text { seen during pregnancy }\end{array}$ \\
\hline $\begin{array}{l}\text { IPGMER, } \\
\text { Kolkata, India } \\
\text { (2012) [14] }\end{array}$ & 29 & $29(100 \%)$ & $20(86.9 \%)$ & $\begin{array}{l}23 \\
(89.7 \%)\end{array}$ & $\begin{array}{l}1(5.8 \%)- \\
\text { CVA }\end{array}$ & Yes & NA & $\begin{array}{l}\text { Yes- } \\
\text { Healthy }\end{array}$ & $\begin{array}{l}\text { Conception usually spontaneous, } \\
\text { Disease not active }\end{array}$ \\
\hline $\begin{array}{l}\text { Osaka, Japan } \\
\text { (2014) [19] }\end{array}$ & 27 & $5(18.5 \%)$ & $4(14.8 \%)$ & $\begin{array}{l}27 \\
(100 \%)\end{array}$ & 0 & No & 3 & No & Ishikawa stage II fares worse \\
\hline $\begin{array}{l}\text { Istanbul } \\
\text { University, } \\
\text { Turkey (2015) } \\
\text { [20] }\end{array}$ & 19 & $3(16 \%)$ & $1(5.2 \%)$ & $\begin{array}{l}19 \\
(100 \%)\end{array}$ & 0 & No & $2(10.5 \%)$ & $\begin{array}{l}\text { Yes-TA } \\
\text { before } \\
\text { diagnosis }\end{array}$ & $\begin{array}{l}\text { TA pregnancies have favorable } \\
\text { outcome }\end{array}$ \\
\hline $\begin{array}{l}\text { Multicentre } \\
\text { Paris, France } \\
\text { (2015) [21] }\end{array}$ & 98 & $26(27 \%)$ & $13(16.7 \%)$ & $\begin{array}{l}78 \\
(79.6 \%)\end{array}$ & 0 & No & $6(6.1 \%)$ & $\begin{array}{l}\text { Yes-TA } \\
\text { before } \\
\text { diagnosis }\end{array}$ & $\begin{array}{l}\text { Smoking and NIH score }>1 \text { predict } \\
\text { poor outcomes }\end{array}$ \\
\hline $\begin{array}{l}\text { CMC, Vellore, } \\
\text { India [22] }\end{array}$ & 16 & $7(43.8 \%)$ & $7(43.8 \%)$ & $\begin{array}{l}16 \\
(100 \%)\end{array}$ & 0 & NA & $4(25 \%)$ & No & $\begin{array}{l}\text { Good outcomes are seen in type } \mathrm{V} \\
\text { disease when in remission }\end{array}$ \\
\hline $\begin{array}{l}\text { Multicentric, } \\
\text { Oslo, Norway } \\
\text { (2017) [9] }\end{array}$ & 37 & $17(29.3)$ & $12(32 \%)$ & $25(68)$ & $\begin{array}{l}0 \text { ( } 1 \text { had } \\
\text { stroke) }\end{array}$ & No & $10(60 \%)$ & $\begin{array}{l}\text { Yes-TA } \\
\text { before } \\
\text { diagnosis }\end{array}$ & $\begin{array}{l}\text { Maternal and foetal outcomes } \\
\text { were favourable. }\end{array}$ \\
\hline $\begin{array}{l}\text { Tel Aviv, Israel } \\
\text { (2018) [23] }\end{array}$ & 20 & $8 / 13(61.5 \%)$ & $9(45 \%)$ & $\begin{array}{l}13 \\
(65 \%)\end{array}$ & 0 & No & NA & No & $\begin{array}{l}\text { Targeted treatment of high blood } \\
\text { pressure emphasised }\end{array}$ \\
\hline $\begin{array}{l}\text { Ankara, Turkey } \\
\text { (2019) [24] }\end{array}$ & 22 & $8(36.4)$ & 18 (81.8\%) & $\begin{array}{l}16 \\
(72.7 \%)\end{array}$ & 0 & No & $\begin{array}{l}5 \text { relapsed } \\
\text { during } \\
\text { pregnancy }\end{array}$ & No & $\begin{array}{l}\text { Almost half had disease relapse } \\
\text { during pregnancy }\end{array}$ \\
\hline $\begin{array}{l}\text { Current study, } \\
\text { Lucknow, } \\
\text { India }\end{array}$ & 38 & 15 (39.5\%) & 12 (63.2\%) & $\begin{array}{l}19 \\
(50 \%)\end{array}$ & 0 & Yes & $\begin{array}{l}15(7.25- \\
18)^{\mathrm{a}}\end{array}$ & $\begin{array}{l}\text { Yes-TA } \\
\text { before } \\
\text { diagnosis }\end{array}$ & $\begin{array}{l}\text { Wong's score useful, ITAS needs } \\
\text { evaluation in larger cohort }\end{array}$ \\
\hline
\end{tabular}

MI myocardial infarction, NA Not available, NIH National Institute of Health indices index

a Median (IQR) CVA, cerebrovascular accident

the type of TA could be one factor although absence of uniform angiographic study in patients limits our ability to comment on that. In most other series angiographic type I and II predominate while our patients mostly had type $\mathrm{V}$ disease $[8,9]$. This involvement of the abdominal aorta with or without renal artery involvement may be leading to pregnancy losses. Also noteworthy is that one-third (6 cases) had medical termination of pregnancy due to various reasons like unwanted pregnancy, conceived while on methotrexate, radiation exposure but only in one case reason was directly attributed to the disease (uncontrolled hypertension).

Poor obstetric care in a developing nation could be another reason. It has been previously shown from our hospital that women with inflammatory myositis, suffer from much poorer maternal outcomes than reported from other countries [10]. However, since the type of TA and consequently patterns of vascular involvement also differ geographically, it might be difficult to allocate attributability to poor outcomes from disease phenotype viz. a viz. socio-economic impact.

While Wong's score for prediction of outcomes in neonates of mothers with TA has been described way back in 1983 , it not being used in routine practice $[8,9,12$, 13]. In our scenario, this may, in fact, be the best predictor for poor neonatal outcome. The study from eastern India also had found similar significance of the Wong score [14]. The other study from Chandigarh, India also found that abdominal aorta involvement (one of the components of Wong's score) portends poorer obstetric outcomes [13]. The fact that Wong's score $>4$ predicted low birth weight suggest that this simple tool 
should find application in the clinic and rheumatologists and obstetrician should get together in this initiative to improve obstetric care in this morbid disease.

Another multicentre study from France found that (National Institute of Health) $\mathrm{NIH}$ score $>1$ predicts poor prognosis [21]. Our data was limited, and we could not calculate the NIH score. However, the ITAS score or DEI.TaK or TADS score could not predict obstetric outcomes. This may be a type 2 error due to small numbers. But it is more likely that ITAS did not show a correlation because mostly the patients in remission had gotten pregnant. The fact that there was no correlation with the TADS score (as compared to the Wong score) seems to imply that abdominal aorta involvement and hypertension were better predictors than overall damage score. However, these need evaluation in a larger cohort. A recent study from India failed to establish utility of ITAS in 16 women although this could be as most women were in remission [22].

Peripartum onset of disease is seen in many autoimmune diseases $[10,24]$. In TA which tends to be latent in a subset of individuals, the altered hemodynamics of pregnancy can lead to decompensation and consequent diagnosis. Our observations were comparable to those of others; although notably, only $25 \%$ of those diagnosed in the peripartum period had prior symptoms.

This study has the advantage of being one of the largest data set relating to obstetric outcomes from a single centre so far. The utility of TADS and DEI.TaK is being explored for the first time. However, the study has its limitations since data was collected retrospectively and used disease but not healthy controls for comparisons. The interviews can have a recall bias.

The results suggest that improved patient counselling and close watch for foetal well-being at a tertiary care centre should be provided to women of childbearing potential. Incorporation of Wong's score in the clinic can be useful to predict outcomes and institute higher priority care.

\section{Conclusion}

Women with Takayasu's arteritis suffer from 1.5-fold higher complications and poor maternal (RR 3.9) as well as fetal (RR 2.0) outcomes. Wong's scoring is useful to predict fetal outcomes.

\section{Acknowledgements}

None.

\section{Authors' contributions}

$L G, D P M, S A, A J$ and $A Z$ co-wrote the manuscript and all authors have reviewed and approved it. $L G, S A$, and $A Z$ compiled and analysed the data.

\section{Funding}

Not applicable.

\section{Availability of data and materials}

Yes

Ethics approval and consent to participate

Waiver of consent taken.

Consent for publication

Yes

\section{Competing interests}

The authors declare that they have no competing interests.

Received: 19 August 2019 Accepted: 17 February 2020

Published online: 12 March 2020

References

1. Misra R. Takayasu arteritis: a distinct syndrome of large vessel vasculitis: a view point by late Professor Paul bacon. Int J Rheum Dis. 2019;22(Suppl 1): 49-52.

2. Misra DP, Wakhlu A, Agarwal V, Danda D. Recent advances in the management of Takayasu arteritis. Int J Rheum Dis. 2019;22(Suppl 1):60-8.

3. Seyahi E. Takayasu arteritis: an update. Curr Opin Rheumatol. 2017;29(1):51-6.

4. Sreih AG, Alibaz-Oner F, Easley E, Davis T, Mumcu G, Milman N, et al. Healthrelated outcomes of importance to patients with Takayasu's arteritis. Clin Exp Rheumatol. 2018;111(2):51-7.

5. Østensen M. Sexual and reproductive health in rheumatic disease. Nat Rev Rheumatol. 2017;13(8):485-93.

6. Machen L, Clowse MEB. Vasculitis and pregnancy. Rheum Dis Clin N Am. 2017;43(2):239-47

7. Pagnoux C, Mahendira D, Laskin CA. Fertility and pregnancy in vasculitis. Best Pract Res Clin Rheumatol. 2013;27(1):79-94.

8. Comarmond C, Biard L, Lambert M, Mekinian A, Ferfar Y, Kahn J-E, et al. Longterm outcomes and prognostic factors of complications in Takayasu arteritis: a multicenter study of 318 patients. Circulation. 2017;136(12):1114-22.

9. Gudbrandsson B, Wallenius M, Garen T, Henriksen T, Molberg $\varnothing$, Palm $\varnothing$. Takayasu arteritis and pregnancy: a population-based study on outcomes and mother/child-related concerns. Arthritis Care Res. 2017;69(9):1384-90.

10. Gupta L, Zanwar A, Ahmed S, Aggarwal A. Outcomes of pregnancy in women with inflammatory myositis: a retrospective cohort from India. J Clin Rheumatol Pract Rep Rheum Musculoskelet Dis. 2019. [Epub ahead of print]. https://doi. org/10.1097/RHU.0000000000000996. PubMed PMID: 30720702.

11. Goel R, Danda D, Joseph G, Ravindran R, Kumar S, Jayaseelan V, et al. Longterm outcome of 251 patients with Takayasu arteritis on combination immunosuppressant therapy: single Centre experience from a large tertiary care teaching hospital in southern India. Semin Arthritis Rheum. 2018;47(5): 718-26.

12. Sharma BK, Jain S, Vasishta K. Outcome of pregnancy in Takayasu arteritis. Int J Cardiol. 2000;75(Suppl 1):S159-62.

13. Suri V, Aggarwal N, Keepanasseril A, Chopra S, Vijayvergiya R, Jain S. Pregnancy and Takayasu arteritis: a single Centre experience from North India. J Obstet Gynaecol Res. 2010;36(3):519-24.

14. Mandal D, Mandal S, Dattaray C, Banerjee D, Ghosh P, Ghosh A, et al. Takayasu arteritis in pregnancy: an analysis from eastern India. Arch Gynecol Obstet. 2012;285(3):567-71.

15. Misra R, Danda D, Rajappa SM, Ghosh A, Gupta R, Mahendranath KM, et al. Development and initial validation of the Indian Takayasu clinical activity score (ITAS2010). Rheumatol Oxf Engl. 2013;52(10):1795-801.

16. Aydin SZ, Merkel PA, Direskeneli H. Outcome measures for Takayasu's arteritis. Curr Opin Rheumatol. 2015;27(1):32-7.

17. Wong VC, Wang RY, Tse TF. Pregnancy and Takayasu's arteritis. Am J Med. 1983;75(4):597-601.

18. de Jesús GR, Klumb EM, de Jesús NR, Levy RA. Pregnancy may Aggravate Arterial Hypertension in Women with Takayasu arteritis. Isr Med Assoc J. 2012;14(12):724-8

19. Tanaka H, Tanaka K, Kamiya C, Iwanaga N, Yoshimatsu J. Analysis of pregnancies in women with Takayasu arteritis: complication of Takayasu arteritis involving obstetric or cardiovascular events. J Obstet Gynaecol Res. 2014;40(9):2031-6.

20. Alpay-Kanitez N, Omma A, Erer B, Artim-Esen B, Gül A, Inanç M, et al. Favourable pregnancy outcome in Takayasu arteritis: a single-centre experience. Clin Exp Rheumatol. 2015;33(2 Suppl 89):S-7-10. 
21. Comarmond C, Mirault T, Biard L, Nizard J, Lambert M, Wechsler B, et al. Takayasu arteritis and pregnancy. Arthritis Rheumatol Hoboken NJ. 2015; 67(12):3262-9.

22. David LS, Beck MM, Kumar M, Rajan SJ, Danda D, Vijayaselvi R. Obstetric and perinatal outcomes in pregnant women with Takayasu's arteritis: single Centre experience over five years. J Turk Ger Gynecol Assoc. 2019. https:// doi.org/10.4274/jtgga.galenos.2019.2019.0115 [Epub ahead of print].

23. Kirshenbaum M, Simchen MJ. Pregnancy outcome in patients with Takayasu's arteritis: cohort study and review of the literature. J Matern-Fetal Neonatal Med Off J Eur Assoc Perinat Med Fed Asia Ocean Perinat Soc Int Soc Perinat Obstet. 2018:31(21):2877-83.

24. Tanacan A, Unal C, Yucesoy HM, Duru SA, Beksac MS. Management and evaluation of pregnant women with Takayasu arteritis. Arch Gynecol Obstet. 2019;299(1):79-88.

\section{Publisher's Note}

Springer Nature remains neutral with regard to jurisdictional claims in published maps and institutional affiliations.

Ready to submit your research? Choose BMC and benefit from:

- fast, convenient online submission

- thorough peer review by experienced researchers in your field

- rapid publication on acceptance

- support for research data, including large and complex data types

- gold Open Access which fosters wider collaboration and increased citations

- maximum visibility for your research: over $100 \mathrm{M}$ website views per year

At $\mathrm{BMC}$, research is always in progress.

Learn more biomedcentral.com/submissions 